\title{
A városi környezet nagygombavilága - fajösszetételének és változásainak jellegzetességei
}

\author{
Csizmár Mihály, Tóth Annamária és Bratek Zoltán \\ ELTE TTK Növényélettani és Molekuláris Növénybiológiai Tanszék \\ 1117 Budapest, Pázmány Péter stny. 1/C \\ e-mail:csimiz@gmail.com
}

\begin{abstract}
Összefoglaló: A természetközeli területek jelentős része már városi környezetté „avanzsálódott”, az eredeti élőhelyek átalakultak, fragmentálódtak. A városok gombavilága kevésbé kutatott, a téma ismeretanyaga hiányos. Jelen munka 1987 és 2017 közötti időszak városi, föként budapesti mikológiai gyüjtéseit dolgozza fel. A 30 év alatt 296 gombataxon került regisztrálásra, összesen 1053 adattal. A fellelt gombák 52 családba és 126 nemzetségbe tartoznak. A legfajgazdagabb nemzetségek az Inocybe (22 faj), Hebeloma (12 faj) és Agaricus ( 8 faj). Leggyakoribb fajok a Conocybe deliquescens, az Agaricus bitorquis, a Panaeolina foenisecii, a Coprinellus micaceus aggr. és a Scleroderma bovista. A szaprotróf életmódot folytató taxonok aránya a legmagasabb, $62 \%$, a mikorrhizásoké $32 \%$, míg a parazitáké $6 \%$. A fellelt gombák $55 \%$-a szerepel a magyarországi nagygombák javasolt Vörös Listáján, illetve négy védett faj is elökerült: Battarrea phalloides, Pogonoloma macrocephalum, Volvariella bombycina és Hypsizygus ulmarius. Nyolc indikátor gombafaj jelenlétét igazoltuk, melyből 7 antropogén hatást jelez.
\end{abstract}

Kulcsszavak: városi gomba, urbánus élőhelyek, nagygomba

\section{Bevezetés}

Az egész világra jellemző urbanizációs folyamatoknak köszönhetően Magyarország népességének a jelentős része is mára már a városokban él. A városi lét jellemző velejárója, hogy az ottani lakosság igényei megnőnek, nagyobb kényelmet és jólétet szoknak meg és várnak el. A növekvő igények kielégítéséhez szükséges ipar, mezőgazdaság és a szolgáltatói szféra fejlesztése pedig nem csak a városi környezetben zajlik le, hanem az agglomerációban és a vidéki térségekben is. Ennek eredményeképpen a természetközelibb, érintetlen területek és az épített környezet aránya jelentősen megváltozott. Az eddig megszokott élőhelyek kis,- vagy teljes mértékben, de átalakultak. 2005 és 2030 között a világ városi területeinek mérete várhatóan $250 \%$-kal fog növekedni, ez azt jelenti, hogy elérheti majd az 1,1 millió $\mathrm{km}^{2}$-t is (Angel et al. 2005). Az átformált területeken új típusú, külön- 
leges életfeltételekkel rendelkező élőhelyek keletkeznek és nyílnak meg a friss kolonizálók számára. Ilyen élőhelyek például a kertek, parkok, út- és vízmellékek gyepei és ültetett fasorai. Ezek az újonnan keletkezett habitatok kezdetben üresek, a folyamatos zavarás és a gyakori gyors változások miatt, adott intervallumon belül sem alakul ki egyensúlyi helyzet az élőhelyeken, ezért több (ritka) fajnak szolgálhatnak kiugrási-elterjedési lehetőségként (Pál-fám 2006). Gondoljunk csak a városi parkok meghagyott idős fáit parazitáló védett gombákra, mint az óriás bocskorosgomba (Volvariella bombycina). A legnagyobb változáson átesett részek a városok, amelyek jellemzően jó természeti adottságú területeken fekszenek, helyükön keletkezésük elött gazdag élővilág honolt. Budapest például éppen a sík és hegyvidék találkozásánál alakult ki, ezért megannyi változatos élőhely fellelhető itt, amelyeket a Duna választ el egymástól. Megtalálható a dolomit sziklagyepektől kezdve a homokbuckákon át a lápokig mindenfajta élőhely, amely számos élőlénynek adott és ad otthont ma is (Bajor 2015). Így már jobban érthető az is, hogy mekkora a szerepük a városi zöldterületeknek, hiszen egyszerre jelentenek menedéket az eredeti élővilág fennmaradt képviselőinek, illetve képesek kapcsolatot tartani a települések által felszabdalt, eredetileg összefüggő területtel rendelkező élőhelyek között. Jelen munka célja, hogy a hosszútávú megfigyelések adatainak elemzésével információkat adjon közre a városi környezet gombavilágának összetételéről. Rámutasson mely fajok azok, amelyek jobban elviselik a speciális körülményeket (taposás, bolygatás, szennyezés...) és képesek erős állományokat létrehozni. Próbálunk rávilágítani az egyes gombataxonok elterjedését befolyásoló, háttérben álló okokra is. Ezen megfigyelési, és gyakorisági adatok hozzájárulhatnak Magyarország kalaposgombáinak védelméhez, továbbá gyarapítják az urbánus területek egyébként igen hiányos mikológiai ismeretanyagát.

\section{Módszerek}

A felhasznált adatokat az ELTE TTK Növényélettani és Molekuláris Növénybiológiai Tanszék fungáriumi anyagai és Babos Margit mikológus zuglói gyüjtései szolgáltatták közel fele-fele arányban. Az alkalomszerü felvételezések az 1987 és 2017 közötti időszakban történtek, összesen 614 alkalommal. A terepbejárások jellemzően a csapadékos őszi-nyári időszakokra estek, azonban találunk minden évszakban feljegyzéseket. A gyüjtések nagyrésze Budapesten a XIV. és a XI. kerületekben történtek, föként kertváros jellegü élőhelyeken, de elenyésző számú gombaadat a föváros más részein is rögzítésre került, mint a XXII., XV., XII., és X. kerületek. Néhány egyéb város területéről is származnak gombaadatok, pl. Kerepes, Debrecen, Gödöllő, Dunavarsány, Budakalász (összesen kb. 15 \%-a az 
adatoknak). Az epigeikus és hipogeikus gombák egyaránt regisztrálásra kerültek. A begyüjtött taxonok határozási munkáinak javarészét a szerzők és Babos Margit végezték a következö irodalmak segítségével: Knudsen és Vesterholt (2012), Krieglsteiner (2000, 2001, 2003), Krieglsteiner és Gminder (2010), Montecchi és Sarasini (2000), Moser (1993), Rimóczi és Vetter (1990). A fajlistában szereplő anyagokból szárított fungáriumi példány készült, melyek a Tanszéki gyüjteményben találhatóak meg, továbbá szerepelnek az Első Magyar Szarvasgombász Egyesület adatbázisában is (Merényi et al. 2010). Az esetek túlnyomó részében faji szintig történt a határozás. Nikon Optiphot-2 típusú mikroszkópot, kémiai reagenseket, speciális esetekben pedig molekuláris biológiai módszereket (PCR - technikák) használtunk a határozási munkák során (Gardes és Bruns 1993, White és mtsai 1990). A nevezéktanban az IndexFungorum-ot (CABI 2017) vettük alapul, míg a családbesorolásnál a MycoBank 2017-es internetes adatbázisra támaszkodtunk (MycoBank 2017). A funkcionális csoportok szerinti értékelést az Arnolds és mtsai (1995) által kidolgozott kategóriák alapján végeztük (2. táblázat). Az indikátor gombák és tulajdonságaik leírásához Benedek (2011) és Pál-Fám (2006) munkáit használtuk fel.

\section{Eredmények}

Munkánk során 296 gombataxon előfordulását, összesen 1053 adattal sikerült városi (erősen urbánus) környezetből kimutatni. 221 taxon a Basidiomycota, míg 75 az Ascomycota törzsbe tartozik. A fellelt gombák 52 családból és 126 nemzetségből kerültek ki. A legfajgazdagabb nemzetségeknek az Inocybe (susulyka), Agaricus (csiperke) és Hebeloma (fakógomba) bizonyultak (1. táblázat). Alegtöbbször előkerült föld felett termőtestet hozó fajok a kérész haranggomba (Conocybe deliquescens) 70 adattal 9 különbözö évböl, az ízletes csiperke (Agaricus bitorquis) 49 adattal 12 különböző évből, a réti trágyagombácska (Panaeolina foenisecii) 47 adattal 12 különböző évből, a kerti tintagomba (Coprinellus micaceus aggr.) 40 adattal, 15 különböző évből és a fakó áltrifla (Scleroderma bovista) 33 adattal 5 különböző évböl. További gyakori fajok voltak még a gyapjas tintagomba (Coprinus comatus) 25 adattal, 9 különbözö évböl, a sötétlábú fakógomba (Hebeloma mesophaeum) 20 adattal, 6 különböző évből és a begöngyöltszélü cölöpgomba (Paxillus involutus aggr.) 19 adattal, 7 különböző évből. A földalatti

1. táblázat. Leggyakrabban előkerült nemzetségek a fajok száma szerint.

\begin{tabular}{cccccccc}
\hline $\begin{array}{c}\text { Inocybe } \\
\text { sp. }\end{array}$ & $\begin{array}{c}\text { Hebeloma } \\
\text { sp. }\end{array}$ & $\begin{array}{c}\text { Agaricus } \\
\text { sp. }\end{array}$ & $\begin{array}{c}\text { Helvella } \\
\text { sp. }\end{array}$ & $\begin{array}{c}\text { Lepiota } \\
\text { sp. }\end{array}$ & $\begin{array}{c}\text { Coprinellus } \\
\text { sp. }\end{array}$ & $\begin{array}{c}\text { Psathyrella } \\
\text { sp. }\end{array}$ & $\begin{array}{c}\text { Tuber } \\
\text { sp. }\end{array}$ \\
\hline 22 & 12 & 8 & 8 & 8 & 7 & 7 & 7 \\
\hline
\end{tabular}


(hipogeikus) gombavilág gyakori fajai: rőt szarvasgomba (Tuber rufum aggr.) 7 adattal 4 különböző évből, citromsárga hártyáspöfeteg (Hymenogaster citrinus) 6 adattal 3 különböző évből, sima hártyáspöfeteg (Hymenogaster bulliardii) 5 adattal 5 különböző évből, kocsonyáspöfetegek (Melanogaster spp.) 4 adattal 4 különböző évből. Munkánk során több különleges gombafaj előfordulását is sikerült feljegyeznünk úgy, mint a hungarikum, csak a Duna által deponált homoktalajokon növő homoki szarvasgombát (Mattirolomyces terfezioides) kertekből, temetőkből; a trópusi sárga bordásőzlábgombát (Leucocoprinus birnbaumii) szobanövények mellől; vagy a gasztronómiai értéke miatt híressé vált nyári szarvasgombát (Tuber aestivum) városi fák alól. Előkerült több indikátor gombafaj is, melyek döntően antropogén hatásokat indikálnak. Magas nitrogén tartalmat jelző gombák: kerti rétgomba (Agrocybe dura), büdös őzlábgomba (Lepiota cristata), szürkepikkelyü csengettyügomba (Pluteus ephebeus); zavarást és bolygatást jelző fajok: narancsszínü csészegomba (Aleuria aurantia), nagy őzlábgomba (Macrolepiota procera); nem megfelelö környezetet az ültetett fák számára: téli fülőke (Flammulina velutipes) és Volvariella bombycina. Az egyetlen természetes állapotot jelző, városba bekényszerült, de ott erős populációt létrehozó védett faj pedig a laskapereszke (Hypsizygus ulmarius) volt.

\section{Értékelés}

Az eredmények mikológiai szempontú értékelése

Elmondható, hogy a vizsgált városi környezet is viszonylagosan gazdag fungával rendelkezik. A 296 gombataxon, amelyet sikerült regisztrálnunk arra enged következtetni, hogy megannyi faj sikeresen vette az emberek által eléjük gördített akadályokat és képesek voltak az átalakított élőhelyek kolonizációjára. A leggyakrabban előkerült fajok nem meglepő módon kozmopoliták, tehát igen széleskörú elterjedéssel rendelkeznek, föként a mérsékelt égövön belül. Ilyenek az Agaricus bitorquis, a Panaeolina foeniseci és a Coprinellus micaceus aggr., urbánus területek gombáiként közismert fajok. Söt az Agaricus bitorquis elhíresült arról, hogy a legszélsőségesebb körülmények között is képes termőtestet hozni, akár a betont áttörni. Az öntözött kertek, parkok és füves területek oázisként müködnek az egyébként, a „városi hősziget hatás” és a csapadékvíz öntözőcsatornákba való elfolyása miatt rendkívül száraz nagyobb településeken. A rendszeres öntözésnek köszönhetően, (ami akár helyenként megduplázhatja az éves „lehulló csapadékot”!) ezek az élőhelyek kitüntetetté válnak bizonyos szaprotróf gombafajok számára. Tipikusan ilyenek a Conocybe deliquescens, Panaeolina foenisecii és Coprinus comatus jelen munkában is gyakori fajok. Érdekes megfigyelés, hogy 
a Conocybe deliquescens fajról egészen 2008-ig számos feljegyzés van, azonban az azt követő években eltüntek vagy jelentősen megfogyatkoztak, adat nincsen róluk. Városi fasorok, parkok és kertek frekventáltan előforduló ektomikorrhizaképző fafajai a Tilia spp., Populus spp., Betula pendula, Picea spp., Abies spp., illetve újabban a Carpinus betulus és Ulmus spp. fajai. Bár az ektomikorrhizás fafajok kevésbé elterjedtek a városi környezetben, mégis helyenként nagy termötest produktivitású gombaközösségek alakulnak ki alattuk. Meglepően népes fajszámmal regisztráltuk a mikorrhizás Inocybe (22 faj), illetve a Hebeloma (12 faj) nemzetséget. Leggyakrabban elökerült gyökérkapcsolt gombák pontosan azok a fajok, amelyek képesek a fent felsorolt gyakori gazdanövények legtöbbjével kapcsolatot kialakítani. A Scleroderma bovista és a Paxillus involutus aggr. termőtestei nyáron jelennek meg tömegesen a megfelelö időjárás esetén, míg a Hebeloma mesophaeum inkább őszi, késő őszi gomba. A zöldülőtönkủ susulyka (Inocybe aeruginascens) ektomikorrhizás gombafaj gazdanövény fajcseréjét figyeltük meg. A városokban előforduló példányok az ültetett hársfákkal (T. cordata és $T$. tomentosa) illetve nyírfákkal (B. pendula) képeznek elsősorban mikorrhizakapcsolatot, holott a természetközeli élöhelyeken legelterjedtebb partnerei a nyárfák (Populus alba és P. nigra).

\section{A taxonok funkcionális csoportok (életmód) szerinti értékelése}

A taxonok funkcionális csoportok szerinti megoszlását a 2. táblázat mutatja be (pn = nekrotróf parazita, st = talajlakó szaprotróf, sk = egyéb növényi maradványokon élő szaprotróf, $\mathrm{sh}=$ fán élő szaprotróf, $\mathrm{sc}=$ koprofil, $\mathrm{m}=$ mikorrhizás, $\mathrm{pb}=$ biotróf parazita). A szaprotróf életmódot (st, sh, sk, sc kategóriák) folytató fajok részesedése $62 \%$, a mikorrhizásoké $32 \%$, míg a parazitáké (pn, pb) $6 \%$. A szaprotrófok magas aránnyal szerepelnek, annak ellenére is, hogy számos gyüjtés a föld alatt élő, kizárólag gyökérkapcsolt gombafajokra volt specializálva. A kialakult arányok hátterében több lehetséges ok is állhat. Az urbánus területekre jellemző $\mathrm{N}$ koncentráció növekedés kedvezötlenül hat a mikorrhizás gombák elterjedésére, míg a korhadéklakó gombák kedvelik a nitrogénben gazdag területeket és köztudottan jobban elviselik a bolygatást is (Arnolds 1991; Hogberg et al. 2003). A mikorrhizás gombák számának csökkenését már több városban is kimutatták (Newbound et al. 2010). Krakkóban például főképp a fenyőfélék mikorrhiza-gombáinak csökkenését figyelték meg (Woiewoda 1991). Egy másik

2. táblázat. Fellelt taxonok funkcionális csoportok szerinti megoszlása $(\mathrm{pn}=$ nekrotróf parazita, st = talajlakó szaprotróf, sk = egyéb növényi maradványokon élő szaprotróf, sh = fán élő szaprotróf, $\mathrm{sc}=$ koprofil, $\mathrm{m}=$ mikorrhizás, $\mathrm{pb}=$ biotróf parazita).

\begin{tabular}{ccccccc}
\hline $\mathrm{st}$ & $\mathrm{m}$ & $\mathrm{sh}$ & $\mathrm{pn}$ & $\mathrm{sk}$ & $\mathrm{pb}$ & $\mathrm{sc}$ \\
\hline 110 & 96 & 63 & 16 & 8 & 2 & 1 \\
\hline
\end{tabular}


lehetséges ok a városi mikorrhiza-partner fák kis egyedszáma és fajgazdagsága. Jellemzően nem ektomikorrhizás „várostüro"” fafajokat telepítenek, mint az ostorfa (Celtis spp.), kőris (Fraxinus spp.), platán (Platanus spp.) vagy juhar (Acer spp.), ezért a gombák nem találják meg szimbionta partnereiket. A viszonylag nagyobb számban jelenlévő nekrotróf paraziták (pn: 19 taxon) pedig a városi fák gyengébb egészségi állapotára utalhatnak (Pál-Fám 2006).

\section{Természetvédelmi értékelés}

Jelen munkában szereplő taxonok 55\%-a szerepel a magyarországi nagygombák javasolt Vörös Listáján (3. táblázat) (Rimóczi és mtsai. 1999). Az érték megha-

3. táblázat. Vörös Listás taxonok száma IUCN kategóriák szerint.

\begin{tabular}{cccc}
\hline VL: 1 & VL: 2 & VL: 3 & VL: 4 \\
\hline 2 & 21 & 97 & 44 \\
\hline
\end{tabular}

ladja sok más, természetközeli élőhelyen végzett felmérésben tapasztalt értéket! Ráadásul 2 igazán ritka „eltünéssel vagy kihalással fenyegetett” (IUCN 1) faj, a komposztcsiperke (Agaricus subperonatus) és a különleges, gyógyhatása miatt jelentős mennyiségben termesztett vörös rovarrontógomba (Cordyceps militaris) is több alkalommal elökerült. A jogilag védett 58 faj közül négyet sikerült regisztrálnunk: álszömörcsög (Battarrea phalloides), gyökeres álpereszke (Pogonoloma macrocephalum), Volvariella bombycina és Hypsizygus ulmarius. A Battarrea phalloides előszeretettel terem bolygatott homokos területeken. A másik három faj erősen kötődik az idős fákhoz, melyeket a városi parkokban épségben meghagynak. Érdekes jelenség, hogy azok a farontó (xilofág) gombák, melyek szubsztrátuma kizárólag az idős fák lehetnek, nagy számban települnek be a városokba, ahol még megtalálják azokat.

Köszönetnyilvánitás - Köszönjük Babos Lórántnak, hogy rendelkezésünkre bocsájtotta Babos Margit mikológus zuglói gombagyüjtéseit! Köszönettel tartozunk még a határozásban nyújtott segítségért Nagy Istvánnak, Dima Bálintnak, Boros Lajosnak és Merényi Zsoltnak!

\section{Irodalomjegyzék}

Angel, S., Sheppard, S. C. \& Civco, D. L. (2005): The Dynamics of Global Urban Expansion. TheWorld Bank, Washington, DC, $200 \mathrm{p}$.

Arnolds, E., (1991): Decline of ectomycorrhizal fungi in Europe. - Agric. Ecosyst. Environ. 35: 209-244. doi: https://doi.org/10.1016/0167-8809(91)90052-Y 
Arnolds, E., Kuyper, Th. W. \& Noordeloos, M. E. (1995): Overzicht van de paddestoelen in Nederland. - Nederlandse Mycologische Vereniging, Wijster, 221 pp.

Bajor Z. (2015): Budapest természeti értékei. - Herman Ottó Intézet, Budapest, 351 p.

Benedek L. (2011): A Központi-Börzsöny nagygombái. - PhD disszertáció, Szent István Egyetem, Budapest.

CABI (2017): http://www.indexfungorum.org (2017. október).

Gardes, M. \& Bruns, T. D. (1993): ITS primers with enhanced specificity for basidiomycetes - application to the identification of mycorrhizae and rusts. - Mol. Ecol. 2: $113-118$. doi: https://doi. org/10.1111/j.1365-294X.1993.tb00005.X

Hogberg, M. N., Baath, E., Nordgren, A., Arnebrant, K. \& Hogberg, P., (2003): Contrasting effects of nitrogen availability on plant carbon supply to mycorrhizal fungi and saprotrophs - a hypothesis based on field observations in boreal forest. New Phytol. 160: 225 -238. doi: https://doi. org/10.1046/j.1469-8137.2003.00867.x

Knudsen, H. \& Vesterholt, J. (szerk.) (2012): Funga Nordica, 2nd edition. - Nordsvamp, Copenhagen, $1083 \mathrm{p}$.

Krieglsteiner, G. J. (szerk.) (2000): Die Grosspilze Baden-Württembergs. 2. - Ulmer, Stuttgart, $620 \mathrm{p}$.

Krieglsteiner, G. J. (szerk.) (2001): Die Grosspilze Baden-Württembergs. 3. - Ulmer, Stuttgart, $634 \mathrm{p}$.

Krieglsteiner, G. J. (szerk.) (2003): Die Grosspilze Baden-Württembergs. 4. - Ulmer, Stuttgart, $467 \mathrm{p}$.

Krieglsteiner, G. J. \& Gminder, A. (szerk.) (2010): Die Grosspilze Baden-Württembergs. 5. - Ulmer, Stuttgart, $672 \mathrm{p}$.

Merényi Zs., Illyés Z., Völcz G. \& Bratek Z. (2010): A database and its application for the development of truffle cultivation methods. - In: Proceedings of the First Conference on the "European" Truffle Tuber aestivum/uncinatum. Öster. Z. Pilzk, 19, pp. 239- 244.

Montecchi, A. \& Sarasini, M. (2000): Funghi ipogei d'Europa. - A.M.B., Trento, 714 p.

Moser, M. (1993): Guida alla determinazione dei funghi. Vol. I. (Die Röhrlinge und Blätterpilze). - Saturnia, Trento.

MycoBank (2017): http://www.mycobank.org (2017. november)

Newbound, M., Mccarthy, M. A., \& Lebel, T. (2010): Fungi and the urban environment: A review. Landsc. Urban Plan. 96: 138-145. doi: https://doi.org/10.1016/j.landurbplan.2010.04.005

Pál-Fám, F. \& Boros, V. (2006): Nagygombák vizsgálata Kaposvár városban. [Macrofungi examination in Kaposvár city]. - Somogyi Múzeumi Közlem. 17: 7-16.

Rimóczi I. \& Vetter J. (szerk.) (1990): Gombahatározó I-II. - Országos Erdészeti Egyesület Mikológiai Társasága, Budapest.

Rimóczi I., Siller I., Vasas G., Albert L., Vetter J. \& Bratek Z. (1999): Magyarország nagygombáinak javasolt Vörös Listája. - Mikol. Közlem. - Clusiana 38: 107-132.

White, T. J., Bruns, T. D., Lee, S. \& Taylor, J. W. (1990): Amplification and direct sequencing of fungal ribosomal RNA genes for phylogenetics. - In: Innis, M.A., Gelfand, D.H., Sninsky, J.J. \& White, T.J. (szerk.): PCR protocols: a guide to methods and applications. Academic Press, New York, 315-322 pp.

Woiewoda W. (1991): Changes in macrofungal flora of Cracow (S. Poland). - Veröff. Geobot. Inst. ETH, Stiftung Rubel, Zürich 106., pp. 150-161. 


\title{
Macrofungi of cities - characteristics of changes and species composition
}

\author{
Mihály Csizmár, Annamária Tóth and Zoltán Bratek \\ ELTE TTK Department of Plant Physiology and Molecular Plant Biology \\ H-1117 Budapest, Pázmány Péter stny. 1/C, Hungary \\ e-mail:csimiz@gmail.com
}

\begin{abstract}
A number of natural landscapes have already been urbanized meanwhile the original habitats have changed and fragmented. The mycota of urban environments is not well researched. In the present work we analyze data of urban mycological surveys between 1987 and 2017. The surveys were performed mostly in Budapest and in few other Hungarian cities. 296 fungal taxa have been documented with 1053 records. All of the species belong to 52 families and 126 genera. The most diverse genera were Inocybe, Agaricus and Hebeloma. Conocybe deliquescens, Agaricus bitorquis, Panaeolina foenisecii, Coprinellus micaceus aggr. and Scleroderma bovista were common species during the years. The ratio of saprotrophic species was the highest with $62 \%$, then mycorrhizal 32 $\%$ and necrotrophic parasite $6 \%$. We found that 163 species $(55 \%)$ are included in the proposed Hungarian Red List of macrofungi, furthermore four protected species (Battarrea phalloides, Pogonoloma macrocephalum, Volvariella bombycina and Hypsizygus ulmarius) were also recorded. We have documented the presence of 8 indicator fungal species and 7 of these indicate anthropogenic disturbance.
\end{abstract}

Keywords: urban fungi, urban habitats, macrofungi 